\title{
Abraham Palatnik : a discipline of chaos ?
}

\author{
MARJOLAINE BEUZARD
}

Marjolaine Beuzard é doutora em História da Arte Moderna e Contemporânea na Universidade Paris-Sorbonne. Em 2016, defendeu tese de doutorado sob a direção do professor Arnauld Pierre, intitulada "Abraham Palatnik, pionnier brésilien de l'art cinétique". Seus interesses de pesquisa incluem arte européia e não-européia, a relação entre arte e ciência, arquitetura, abstração geométrica e práticas multi-médias experimentais da arte cinética à arte cibernética.

AFILIAÇÃO: Université Paris-Sorbonne, Paris, France. 
- RESUME

Ce texte présente à la fois l'artiste Abraham Palatnik, et le contexte et la trajectoire de son œuvre. II a été publié pour la première fois en français à l'occasion de la première exposition personnelle de l'artiste en France en 2012: Palatnik, une discipline du chaos à la galerie Denise René1 à Paris (boulevard Saint Germain, Quartier Latin). La galerie Denise René est chaleureusement remerciée pour cette publication.

MOTS-CLEFS

Abraham Palatnik, galerie Denise René, art cinétique

\section{RESUMO}

Este texto apresenta ao mesmo tempo o artista Abraham Palatnik, o contexto e a trajetória de seu trabalho. Ele foi publicado pela primeira vez em francês na ocasião da primeira exposição pessoal do artista na França em 2012: Palatnik, uma disciplina do caos na galeria Denise René em Paris (Saint Germain boulevard, Latin Quarter). A galeria Denise René é muito agradecida por esta publicação.

\section{PALAVARS-CHAVE}

Abraham Palatnik, galeria Denise René, arte cinética

L'artiste sert à discipliner le chaos perceptif. Je continue à croire au lien entre la perception et l'intuition. Sans elle, la nature ne serait rien d'autre qu'un chaos.

Abraham Palatnik $^{1}$

\footnotetext{
${ }^{1}$ SÁ, Luís Felipe (dir.). Abraham Palatnik : disciplina do caos. Rio de Janeiro : Márcia de Medeiros/Prefeitura da Cidade do Rio de Janeiro (Rioarte Vídeo- Arte Contemporânea), 2005.
} 
Abraham Palatnik appartient à la génération des pionniers de l'art cinétique, qui en Europe, et aux Amériques ont construit cette révolution esthétique et formelle, un art inscrit dans une tradition abstraite, géométrique, construite, fondé sur le mouvement, l'optique, la machine, et la participation du spectateur. Son œuvre liée à quelques événements majeurs de l'art occidental du XXème siècle, interroge le mouvement, le temps, la création artistique, sa relation au monde et une « écologie plastique » en lien avec la nature et ses mécanismes. Avec l'invention du dispositif luminocinétique « ciné-chromatique " présenté à la première Biennale Internationale de São Paulo en $1951^{2}$, Palatnik est considéré comme le fondateur de l'art technologique au Brésil ${ }^{3}$. Depuis le début des années 1940, la galerie Denise René soutient l'abstraction géométrique et entretient des relations avec les artistes sud-américains et leurs critiques comme Mario Pedrosa. A la XXXIlème Biennale de Venise de 1964, Palatnik rencontre la galeriste Denise René. Elle l'invite à participer à l'exposition Mouvement 2 programmée la même année à Paris ${ }^{5}$. Cette exposition rétrospective présente une cinquantaine d'artistes dont Lygia Clark, Carlos Cruz-Diez, Sergio de Camargo, Julio Le Parc, Jesus Rafael Soto... Dix ans après l'exposition « manifeste » de $1955^{6}$, l'exposition Mouvement 2 réaffirmait le succès de l'art optico-cinétique en prise avec son temps.

Né à Natal (Brésil) en 1928, Palatnik vit et travaille à Rio de Janeiro. Sa double formation - artistique et technique - acquise à Tel Aviv (où il séjourne entre 1932 et 1947), puis à Rio de Janeiro à partir de 1948, sa découverte de l'art des fous liée à sa participation en tant qu'intervenant aux ateliers d'art thérapie du Docteur Nise da Silveira et sa rencontre avec le critique d'art Mario Pedrosa vont être déterminantes pour le jeune artiste en développant chez lui une véritable dimension heuristique. Dans le cercle de Mario Pedrosa, il forme avec Almir Mavignier et Ivan Serpa, un premier groupe d'artistes abstraits à Rio de Janeiro. Ses recherches le conduisent à mettre au point « une peinture abstraite dynamique », un dispositif luminocinétique dérivé d'un kaléidoscope motorisé et programmé que qualifie Mario Pedrosa de « ciné-chromatique ${ }^{7}$. L'appareil est présenté et primé dès la Première Biennale de São Paulo en 1951, la même année que Max Bill et Ivan Serpa. Ces distinctions révèlent une tendance constructive et concrète en devenir au Brésil avec la formation du groupe Ruptura à São Paulo en 1952 et celle du groupe Frente à Rio de Janeiro en 1954. La divergence des deux groupes aboutira à la formation du Néoconcrétisme avec la publication de son manifeste rédigé par le poète et critique Ferreira Gullar en 1959. Palatnik qui participe au groupe Frente dissous en 1956, fréquente amicalement les artistes néo-concrets. Sans prendre part à leur groupe, il partage des problématiques communes autour du concept de l'« œil corps », de la question de l'objet et sa relation à l'environnement. Durant cette période, l'artiste in-

\footnotetext{
2 Bienal 50 anos : 1951-2001. Edição de Comemoração do 50oAniversário da I Bienal de São Paulo. São Paulo : Fundação Bienal de São Paulo, 2001.

${ }_{3}$ MORAIS, Frederico. «Abraham Palatnik : um pioneiro da arte tecnológica ». In : Retrospectiva, Abraham Palatnik. Rio de Janeiro/São Paulo : Itaú Cultural, 1999. Réed./reprint in : OSORIO, Luiz Camillo. Abraham Palatnik. São Paulo : Cosac Naify, 2004.

${ }^{4}$ XXXII Biennale Internazionale di Arte Venezia. Venise : Biennale de Venise, 1964.

${ }^{5}$ Mouvement 2, Paris : Galerie Denise René, 1964

${ }^{6}$ Le mouvement, Paris : Galerie Denise René, 1955.

7 PEDROSA, Mario. "The Chromatic Plastic Dynamism of Abraham Palatnik : An Introduction to the First International Biennale of São Paulo ». Tribuna da Imprensa, oct. 1951. Réed./reprint in : Leonardo, vol. 29, $n^{\circ} 2$, 1996.
} 
venteur développe une série de jeux perceptifs et plastiques qui reposent sur la sensation de la forme, le plaisir de jouer, l'expérimentation de phénomènes physiques, temporels et participatifs.

A partir de 1964, Palatnik créé les Objets cinétiques qui sont littéralement des objets en mouvement, des œuvres tridimensionnelles qui se déploient plus ou moins dans l'espace et utilisent parfois les propriétés du magnétisme. Ils ont une parenté avec les Appareils Cinéchromatiques. L'artiste a fait dériver son premier procédé. Le dispositif mécanique de la structure interne auparavant dissimulée derrière un écran est devenu apparent, l'objet même de la recherche esthétique. La série des Objets cinétiques oscille entre " mobiles et dessins ", ces recherches privilégient une «peinture spatialisé » et mouvante. Cinétique P-4 (19962005), présentée dans l'exposition, synthétise le programme esthétique de l'objet.

Un peu avant la création des Objets cinétiques, Palatnik inaugure une recherche picturale avec la série en bois de Jacaranda issue d'une observation insolite de la matière végétale. La première réalisation date de 1962. Le dispositif repose sur une progression visuelle ondulatoire, un rythme qui s'étend horizontalement en suggérant une expansion au-delà de la surface de l'œuvre. C'est en observant des chutes de bois qu'il découvre les potentialités plastiques des éléments végétaux. Les lamelles de bois de Jacaranda délivrent des informations sur l'essence de l'arbre par l'intermédiaire de sa forme, l'empreinte d'un code biologique et temporel programmé par la nature dans la matière. De cette observation, l'artiste - avec quelques manipulations - transforme les déchets naturels en œuvre d'art. Son procédé consiste à réorganiser les lamelles de bois verticalement sur une surface plane. L'opération permet à Palatnik de relier l'homme à son environnement à travers une expérience sensible, une forme « d'écologie plastique ».

Après avoir révélé les potentialités du bois, l'artiste va s'intéresser à celles dissimulées dans le papier cartonné. En 1968, il réalise son premier «Relief Progressif » en carton. Comme pour le bois, il s'intéresse à un élément du quotidien et cherche à lui imprimer une "vie propre » en dévoilant ses qualités virtuelles. Le papier cartonné est travaillé par tranches comme le bois, les lamelles ne sont plus disposées à plat sur la surface du support, elles sont installées verticalement sur le plan. Le dispositif obtenu joue sur des effets optiques, de profondeur où l'espace et la lumière se modifient en fonction de la position du spectateur. Les reliefs de la série développent des mouvements ondulatoires, des plis baroques portés à l'infini selon la formule énoncée par le philosophe français Gilles Deleuze ${ }^{8}$.

A partir des années 1980, Palatnik se consacre exclusivement à la peinture et développe de nouveaux systèmes basés sur l'interaction des couleurs et leurs possibilités dynamogènes. Sa peinture expérimente les conditions de mise en forme des couleurs. Les mélanges optiques produisent des effets de moirages. La structure afocale invite le spectateur à se déplacer. Ce langage visuel est à mettre en relation avec les Physichromies de Cruz-Diez, les reliefs contrapuntiques d'Agam, les trames superposées de Soto ou encore les œuvres cinétiques de Brigitte Riley ou de Vasarely. La série des W, la plus récente de Palatnik, explore l'instabilité de l'univers en expansion et les mécanismes qui le régissent. Des séquences ondulatoires

${ }^{8}$ DELEUZE, Gilles, Le pli, Leibniz et le Baroque, Paris : Éd. de Minuit, 1988, p. 5. 10 KAC, Eduardo, « A pioneer of Kinetic Art. An Interview with Abraham Palatnik ». Folha de São Paulo, 14/10/1986. Réed./reprint in : Leonardo, vol. 29, n² 1996. 
émergent des progressions à l'acrylique sur bois. Le procédé enrichi par un apport chromatique reprend des dispositifs des panneaux en bois de Jacaranda, l'organisation de la surface par un jeu de permutations des lignes verticales. L'emploi des couleurs apporte une grande liberté. La série repose sur deux stratégies formelles : les plages colorées d'un même motif sont décalées graduellement pour obtenir des rythmes ou deux trames distinctes s'interpénètrent verticalement. La transformation cinétique opère : la " matière couleur » se métamorphose en vagues, en vibrations ondulatoires, en paysages « sonores », en musiques sérielles pour un « œil auditif ».

Une lumière colorée transformée en rythmes visuels serait donnée comme ultime étape d'un processus initié dans les années 1940. II a fait exploser une « expression concrète » issue de la " couleur-pigment » pure, évanescente, éthérée, rendue possible par l'emploi d'une lumière directe diffusée derrière un écran, comme un raccourci artistique d'une technologie assumée. Le programme plastique se poursuit par une transposition, à un autre niveau de perception, de la matière inscrite dans ses propres composants immatériels - lumière, espace, temps - pour finalement réintégrer la corporalité de la « matière couleur». Le processus, par des effets de synesthésie, renvoie à une perception connaturelle de l'onde lumineuse et sonore. Avec son œuvre, Palatnik humanise la technique, pour lui « Comprendre l'importance de la forme, non seulement dans le monde extérieur, mais aussi dans les racines inconscientes de l'activité humaine permet de dissoudre les oppositions généralement créées entre l'art, la science, la technologie et la communication. La technologie dans le contexte de l'évolution humaine acquiert une signification et devient évidente dans la mesure où elle permet un accès conscient par les sens aux mécanismes des forces de la nature $\gg$.

\footnotetext{
${ }^{9} \mathrm{KAC}$, Eduardo, «A pioneer of Kinetic Art. An Interview with Abraham Palatnik ». Folha de São Paulo, 14/10/1986. Réed./reprint in : Leonardo, vol. 29, n², 1996.
} 


\section{Abraham Palatnik : a discipline of chaos ? ${ }^{10}$}

\section{ABSTRACT}

This text presents the artist Abraham Palatnik, and the context and trajectory of his work. It was first published in french for the first solo exhibition of the artist in France in 2012 : Palatnik, une discipline du chaos at the gallery Denise René ${ }^{11}$ in Paris, (boulevard Saint Germain, Quartier Latin). The gallery Denise René warmly thanked for this publication.

\section{KEYWORDS}

Abraham Palatnik, Denise René gallery, cinetic art

\section{RESUMO}

Este texto apresenta ao mesmo tempo o artista Abraham Palatnik, o contexto e a trajetória de seu trabalho. Ele foi publicado pela primeira vez em francês na ocasião do primeira exposição pessoal do artista na França em 2012: Palatnik, uma disciplina de caos na galeria Denise René em Paris (Saint Germain boulevard, Latin Quarter). A galeria Denise René é muito agradecida por esta publicação.

\section{PALAVRAS-CHAVE}

Abraham Palatnik, galeria Denise René, arte cinética

The artist masters the perceptif chaos. I still believe there is a link between perception and intuition. Without it, the nature would be nothing else than a chaos.

Abraham Palatnik ${ }^{12}$

\footnotetext{
${ }_{10}$ The translation in English is published for the first time in the Brazilian university review OuvirOuver in 2018 with the acknowledgement of the author. Translated to english by Marjolaine Beuzard.

${ }^{11}$ BEUZARD, Marjolaine. Abraham Palatnik. Une discipline du chaos. Paris : Galerie Denise René, 2012.

12 SÁ, Luís Felipe (dir.). Abraham Palatnik : disciplina do caos. Rio de Janeiro : Márcia de Medeiros/Prefeitura da Cidade do Rio de Janeiro (Rioarte Vídeo- Arte Contemporânea), 2005
} 
Abraham Palatnik belongs to a generation of kinetic art pioneers, whom in Europe and in North and South America have built this formal and aesthetic revolution, an art which registers in an abstract practice, geometrical, constructed tradition, based on the movement, the optics, the machine, and the participation of the spectator. His work bound to some major events of the western art of the XXth century, questions the motion, the time, the art creation, its relation to the world and the "plastic ecology" in connection with the nature and its mechanisms. For the first International Biennal event in São Paulo in $1951^{13}$, Palatnik, who introduced his device lighted-kinetic "kiné-chromatic" was considered the founder of the technological art in Brazil ${ }^{14}$. For a long time, the gallery Denise René got envolved with the geometrical abstraction and maintained relations with the South American artists and their critics such as Mario Pedrosa. In the XXXII Biennial event of Venice of $1964^{15}$ Palatnik meets the gallery owner Denise René. She invites him to introduce his work in the exhibition Movement 2 scheduled the same year in Paris ${ }^{16}$. This exhibition shows about fifty artists among which Lygia Clark, Carlos Cruz-Diez, Sergio de Camargo, Julio Le Parc, Jesus-Rafael Soto ... Ten years after the "obvious" exhibition of $1955^{17}$, the exhibition Movement 2 established the success of optico-kinetic art in grip with his time.

Born in Natal (Brazil) in 1928, Palatnik lives and works in Rio de Janeiro. His double training - artistic and technical - acquired in Tel Aviv (where he stayed between 1932 and 1947), then in Rio de Janeiro from 1948, his discovery of the art of insane bound to its participation as contributor to the workshops of art therapy of Doctor Nise da Silveira and his meeting with the art critic Mario Pedrosa, are going to be essential for the young artist by developing with him a true heuristic dimension. In Mario Pedrosa's circle, he trains a first group of abstract artists in Rio de Janeiro with Almir Mavignier and Ivan Serpa. His searches lead him to work out "a dynamic abstract art", a light kinetic device programmed and derived from a motorized kaleidoscope. Mario Pedrosa considers the device as "Kinechromatic"18. His work presented and obtained an award at the First Biennial of São Paulo in 1951, the same year as Max Bill and Ivan Serpa. These events reveal a constructive and tangible trend developping in Brazilian art, with creations of the group Ruptura in São Paulo in 1952 and the group Frente in Rio de Janeiro in 1954. The divergence of the two groups will lead to the creation of Neoconcretism with the publication of his manifesto written by the poet and critic Ferreira Gullar in 1959. Palatnik, who participated in the group Frente dissolved in 1956, like the company of friendly neo-concrete artists. Without taking part in their group, he shares common issues around the concept of the "body eye", the question of the object and its relation to the environment. During this period, the inventor artist develops a series of perceptive and plastic games that are

\footnotetext{
$\overline{13}$ Bienal 50 anos: 1951-2001. Edição de Comemoração do 50 Aniversário da I Bienal de São Paulo. São Paulo : Fundação Bienal de São Paulo, 2001.

${ }^{14}$ MORAIS, Frederico. « Abraham Palatnik : um pioneiro da arte tecnológica ». In : Retrospectiva, Abraham Palatnik. Rio de Janeiro/São Paulo : Itaú Cultural, 1999. Réed./reprint in : Osorio, Luiz Camillo. Abraham Palatnik. São Paulo : Cosac Naify, 2004.

${ }^{15}$ XXXII Biennale Internazionale di Arte Venezia. Venise : Biennale de Venise, 1964.

${ }^{16}$ Mouvement 2, Paris : Galerie Denise René, 1964.

17 Le mouvement : Galerie Denise René, Paris, 1955.

18 PEDROSA, Mario. "The Chromatic Plastic Dynamism of Abraham Palatnik: An Introduction to the First International Biennale of São Paulo”. Tribuna da Imprensa, oct. 1951. Réed./reprint in : Leonardo, vol. 29, n², 1996.
} 
based on the sensation of form, the pleasure of playing, the experimentation of physical, temporal and participative phenomena.

As of 1964, Palatnik creates the Kinetic Objects that are literally moving objects, three-dimensional works that unfold more or less in space and sometimes use the properties of magnetism. They have a kinship with the Kinechromatics devices. The artist has diverted from his first method. The mechanical device of the internal structure previously hidden behind a screen has become apparent, the very object of aesthetic research. The series of Kinetic objects oscillates between "mobiles and drawings", these researches privilege a "spatialized painting" and moving. Kinetics P-4 (1996-2005), shown in the exhibition, synthesizes the aesthetic program of the object.

A little before the creation of the Kinetic Objects, Palatnik inaugurates a pictorial research with the Jacaranda wood series resulting from an unusual observation of plant matter. The first production dates from 1962. The device is based on an undulatory visual progression, a rhythm that extends horizontally suggesting an expansion beyond the surface of the work. It is by observing falling wood that he discovers the esthetical potential from plants. The slats of Jacaranda wood deliver information about the essence of the tree through its shape, the imprint of a biological and temporal code programmed by nature into matter. From this observation, the artist - with some manipulations - transforms natural waste into a work of art. His process consists of rearranging the slats of wood vertically on a flat surface. The operation allows Palatnik to connect man to his environment through a sensitive experience, a form of "plastic ecology".

After revealing the wood potential, the artist takes a keen interest in revealing what's hidden in the cardboard. In 1968, he made his first "Progressive embossed design" in cardboard. As for wood, he is interested in an element of everyday life and seeks to print a "life of its own" by revealing its virtual qualities. The card stock is worked in slices like wood. The slates are no longer arranged flat on the surface of the support. They are installed vertically on the plane. The result work plays on optical effects of depth, where the space and the light are modified according to the position of the spectator. The embossed design of the series develop undulatory movements, Baroque folds worn to infinity according to the principle stated by the French philosopher Gilles Deleuze ${ }^{19}$.

From the 1980s, Palatnik devoted his wordk exclusively to painting and developed new systems based on the interaction of colors and their dynamogenic possibilities. His painting experiments with the conditions for shaping colors. Optical mixtures produce moire effects. The afocal structure invites the spectator to move. This visual language is to be put in relation with the Physichromies of Cruz-Diez, the contrapuntal reliefs of Agam, the superimposed frames of Soto or the kinetics works of Brigitte Riley or Vasarely. The W series, Palatnik's most recent, explores the instability of the expanding universe and the mechanisms that govern it. Wave sequences emerge from progressions in acrylic on wood. The process enriched by chromatic input takes features of the Jacaranda wood panels, the organization of the surface by a set of permutations of the vertical lines. The use of colors brings a lot of freedom. The series is based on two formal strategies : the colored tracks of the same pattern are shifted gradually to obtain rhythms or two distinct frames interpenetrate

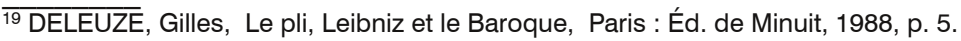


vertically. Kinetic transformation operates : the "color matter" is transformed into waves, wave vibrations, "sound landscapes", serial music for an "auditory eye".

A colored light transformed into visual rhythms would be given as the final stage of a process initiated in the 1940s. It has exploded a "concrete expression" resulting from the pure, evanescent, ethereal "color-pigment" made possible by the use of a direct light diffused behind a screen, as an artistic shortcut of a technology assumed. The plastic program continues with a transposition, to another level of perception, of matter inscribed in its own immaterial components - light, space, time - to finally reintegrate the corporality of the "color matter". The process, through effects of synesthesia, refers to a connatural perception of the light and sound wave. With his work, Palatnik humanizes the technique, for him : "To understand the importance of form, not only in the external world, but also in the unconscious roots of human activity, dissolves the general oppositions created between art, science, technology and communication. Technology in the context of human evolution acquires meaning and becomes evident to the extent that it allows conscious access by the senses to the mechanisms of the forces of nature. ${ }^{20 "}$

\section{Références / References}

BEUZARD, Marjolaine. Abraham Palatnik. Une discipline du chaos. Paris : Galerie Denise René, 2012

Bienal 50 anos : 1951-2001. Edição de Comemoração do 50ㅇ Aniversário da I Bienal de São Paulo. São Paulo : Fundação Bienal de São Paulo, 2001.

MORAIS, Frederico. «Abraham Palatnik : um pioneiro da arte tecnológica ». In : Retrospectiva, Abraham Palatnik. Rio de Janeiro/São Paulo : Itaú Cultural, 1999. Réed./reprint in : OSORIO, Luiz Camillo. Abraham Palatnik. São Paulo : Cosac Naify, 2004.

PEDROSA, Mario. « The Chromatic Plastic Dynamism of Abraham Palatnik : An Introduction to the First International Biennale of São Paulo ». Tribuna da Imprensa, oct. 1951. Réed./reprint in : Leonardo, vol. 29, n² 1996.

SÁ, Luís Felipe (dir.). Abraham Palatnik : disciplina do caos. Rio de Janeiro : Márcia de Medeiros/Prefeitura da Cidade do Rio de Janeiro (Rioarte Vídeo- Arte Contemporânea), 2005.

XXXII Biennale Internazionale di Arte Venezia. Venise : Biennale de Venise, 1964.

Recebido em 25/09/2018 - Aprovado em 17/10/2018

\footnotetext{
$\overline{20}$ KAC, Eduardo, «A pioneer of Kinetic Art. An Interview with Abraham Palatnik ». Folha de São Paulo, 14/10/1986. Réed./reprint in : Leonardo, vol. 29, n², 1996.
}

ouvirouver Uberlândia v. 14 n. 2 p. 300-309 jul.| dez. 2018 
Pour citer cet article / How to cite

BEUZARD , M. Abraham Palatnik : une discipline du chaos ? / Abraham Palatnik : a discipline of chaos? ouvirOUver; Uberlândia, v.14,n.2, p.300-309, jul./dez. 2018.

Disponível em: http://www.seer.ufu.br/index.php/ouvirouver;

DOI:http://doi.org/10.14393/OUV23-v14n2a2018-3

A revista ouvirOUver está licenciada com uma Licença

Creative Commons Atribuição-NãoComercial 4.0 Internacional. 